Annals of Plant and Soil Research 23(1): 88-92 (2021)

https://doi.org/10.47815/apsr.2021.10035

\title{
Influence of organic manures and biofortification of selenium on growth, yieldand selenium contentof cucumber (Cucumis sativus L.)
}

\author{
S. FOWMINA SULAIHA AND A. ANBURANI
}

\begin{abstract}
Department of Horticulture, Faculty of Agriculture, Annamalai University, Annamalai Nagar-608002 (Tamil Nadu) India
\end{abstract}

Received: August, 2020; Revised accepted: November, 2020

\begin{abstract}
Field experiment was conducted to study the influence of organic manures and biofortification of selenium on growth, yield and selenium contentof cucumber (CucumissativusL.) during 2019 at Koneripalayam village in Perambalur district, Tamil Nadu. The popular variety Green Long suitable for this region was used for the present study. The experiment was carried out during two seasonsviz., Season I (February-May) and Season II (July-October)in randomised block design with fifteen treatments and three replications. The results of the experiment revealed that application of $25 \mathrm{tFYM} \mathrm{ha}{ }^{-1}$ and $2 \mathrm{~kg} \mathrm{CBF} \mathrm{ha}^{-1}$ along with foliar application of Se $\left(20 \mu \mathrm{g} \mathrm{L}^{-1}\right)$ significantly recorded the highest vine length $(209.1 \mathrm{~cm}$ and $214.6 \mathrm{~cm})$, number of leaves (108.2 and 113.7), leaf length $(15.7 \mathrm{~cm}$ and $15.9 \mathrm{~cm})$ and leaf breadth $(16.2 \mathrm{~cm}$ and $16.5 \mathrm{~cm})$ in first and second season, respectively. The highest number of fruits per vine (13.3 and 16.5), fruit length (19.6 cm and $20.8 \mathrm{~cm})$, fruit girth $(17.1 \mathrm{~cm}$ and $18.2 \mathrm{~cm})$, mean single fruit weight $(78.1 \mathrm{~g}$ and $81.2 \mathrm{~g})$, fruit yield vine ${ }^{-1}(723.5 \mathrm{~g}$ and $1009.2 \mathrm{~g}$ )and selenium content per fruit $\left(8.1 \mu \mathrm{g} \mathrm{kg}^{-1}\right.$ and $\left.10.6 \mathrm{\mu g} \mathrm{kg}^{-1}\right)$ in first and second season respectively was obtained with1 $t E M \mathrm{ha}^{-1}+2 \mathrm{~kg} \mathrm{CBF} \mathrm{ha}^{-1}+\mathrm{Se}\left(20 \mathrm{\mu g} \mathrm{L}^{-1}\right)$ as foliar application. Among all the organic manures, farmyard manure was proved to be superior in respect of growth parameters and enriched manure in respect of yield parameters. The foliar application of selenium was found to be the best method of its supplementation in plants and relatively higher values of Se content in fruits were noted with higher dose of Se as folior application.
\end{abstract}

Keywords: Organic manures, growth parameters, yield parameters, selenium content, cucumber.

\section{INTRODUCTION}

Cucumber (Cucumissativus L.) is one of the most popular annual vine vegetable belonging to the family Cucurbitaceae. It is the second most widely cultivated and faster maturing cucurbit. Immature tender fruits of cucumber are universally used in the culinary preparation of raitha, salad and pickle. It is rich in vitamins such as, $\mathrm{A}, \mathrm{C}, \mathrm{K}$ and $\mathrm{B} 6$ and also contains minerals especially magnesium, molybdenum, phosphorus, potassium, copper, manganese and dietary fibre.Organic agriculture has been practiced globally in order to promote safe and healthy food and it protects the environment by improving the soil structure, microbial status and soil fertility. The farmyard manure is a bulky organic material that aids in addition of organic matter with excess accumulation of humus content and also improves the crop productivity and sustainability. Enriched manure is a combination of decomposed plant and animal residues containing pressmud enriched with humic acid, amino acid, sea weed extract, rock phosphate and yeast sludge which are gaining importance because of the higher percentage of microbial population it possess when compared to the manures before enrichment. Biofertilizers are an essential and eco-friendly component of organic farming. It contains living cells of nitrogen fixing, phosphate solubilising and potash solubilising microorganisms which are used for the application to seed, soil or plant surface in order to increase the beneficial soil microbes.Selenium is a micronutrient of fundamental importance in ameliorating the human nutrition and plant health. Addition of selenium in human diet helps in reducing the risk of growth retardation, inflammatory conditions, impaired bone metabolism, hypothyroidism, cancer and cardio vascular disease. Hence, World Health Organisation has recommended $50-55 \mu \mathrm{g}$ Se per day in human diet all over the world. Hence, the present experiment was conducted to study the influence of organic manures and biofortification of selenium on growth, yield and selenium contentof cucumber (Cucumissativus L.). 


\section{MATERIALS AND METHODS}

A field experiment was conducted at Koneripalayam village in Perambalur district, (Tamil Nadu) during two seasonsviz., season I (February-May) and season II (JulyOctober).The field area consists of red soil and had a soil pH of 7.1 and electrical conductivity of $1.01 \mathrm{dSm}^{-1}$. The experimental field was situated at $11 \square 13$ ' N latitude and 78 $\square 52$ ' Elongitude at an altitude of $98 \mathrm{M}$ above mean sea level.The experiment was laid out in a randomized block design with three replications and fifteen treatments viz., $\mathrm{T}_{1}-$ (Control - RDF), $\mathrm{T}_{2}-\mathrm{FYM}+$ $\mathrm{CBF}, \mathrm{T}_{3}-\mathrm{FYM}+\mathrm{CBF}+\mathrm{Se}(5 \mu \mathrm{g})$ as soil application, $\mathrm{T}_{4}-\mathrm{FYM}+\mathrm{CBF}+\mathrm{Se}(10 \mu \mathrm{g})$ as soil application, $T_{5}-F Y M+C B F+S e(20 \mu g)$ as soil application, $\mathrm{T}_{6}-\mathrm{FYM}+\mathrm{CBF}+\mathrm{Se}\left(5 \mu \mathrm{L} \mathrm{L}^{-1}\right)$ as foliar application, $\mathrm{T}_{7}-\mathrm{FYM}+\mathrm{CBF}+\mathrm{Se}\left(10 \mu \mathrm{g} \mathrm{L}^{-1}\right)$ as foliar application, $\mathrm{T}_{8}-\mathrm{FYM}+\mathrm{CBF}+\mathrm{Se}(20 \mu \mathrm{g}$ $\left.\mathrm{L}^{-1}\right)$ as foliar application, $\mathrm{T}_{9}-\mathrm{EM}+\mathrm{CBF}, \mathrm{T}_{10}-\mathrm{EM}$ $+\mathrm{CBF}+\mathrm{Se}(5 \mu \mathrm{g})$ as soil application, $\mathrm{T}_{11}-\mathrm{EM}+$ $\mathrm{CBF}+\mathrm{Se}(10 \mu \mathrm{g})$ as soil application, $\mathrm{T}_{12}-\mathrm{EM}+$ $\mathrm{CBF}+\mathrm{Se}(20 \mu \mathrm{g})$ as soil application, $\mathrm{T}_{13}-\mathrm{EM}+$ $\mathrm{CBF}+\mathrm{Se}\left(5 \mu \mathrm{g} \mathrm{L}^{-1}\right)$ as foliar application, $\mathrm{T}_{14}-\mathrm{EM}$ $+\mathrm{CBF}+\mathrm{Se}\left(10 \mu \mathrm{g} \mathrm{L}^{-1}\right)$ as foliar application, $\mathrm{T}_{15}-$ $\mathrm{EM}+\mathrm{CBF}+\mathrm{Se}\left(20 \mu \mathrm{g} \mathrm{L}^{-1}\right)$ as foliar application. The field was thoroughly ploughed and divided into plots of $2 \mathrm{~m} \times 2 \mathrm{~m}$. Three pits per plot were formed and the seeds were sown. The organic manures viz., $25 \mathrm{tFYM} \mathrm{ha}^{-1}, 1 \mathrm{tEM} \mathrm{ha}^{-1}$ along with consortium of biofertilizers@ 2 kg ha ${ }^{-1}$ were incorporated at the time of last ploughing as per the treatment schedule. The selenium was applied in the form of sodium selenatethrough soil and foliar application as per treatment schedule in two split doses viz., 25 and 50 days after sowing. Thinning was done at ten days after sowing by retaining three seedlings per pit. The crop was irrigated every fifth day and proper drainage facilities were provided as the crop cannot withstand water logging. Necessary plant protection measures were carried out as per the recommendation. The fruits of cucumber were harvested when it was tender and green. The fruit takes 7 to 10 days from setting to reach the marketable size. The fruits were picked at every two days interval. The growth parameters viz., vine length, number of leaves, leaf length and leaf breadth. Five plants per plot were randomly selected and tagged for recording observations. The selenium content of fruit was determined by using the Inductively Coupled Plasma - Mass
Spectrometry (ICP-MS) as estimated by A.O.A.C method (2019). The pooled mean data were statistically analysed as per the standard procedure.

\section{RESULTS AND DISCUSSION}

\section{Growth Parameters}

The results (Table 1 ) revealed that the growth parameters viz., vine length, number of leaves, leaf length and leaf breadth were significantly influenced by the supplementation of organic manures along with consortium of biofertilizers and biofortification of selenium at varying levels. The highest vine length $(209.1 \mathrm{~cm}$ and $214.6 \mathrm{~cm}$ ), number of leaves (108.2 and 113.7), leaf length $(15.7 \mathrm{~cm}$ and $15.9 \mathrm{~cm})$ and leaf breadth $(16.2 \mathrm{~cm}$ and $16.5 \mathrm{~cm})$ in first and second season, respectivelywere recorded with $25 \mathrm{t} \mathrm{FYM} \mathrm{ha}^{-1}$ and $2 \mathrm{~kg} \mathrm{CBF} \mathrm{ha}^{-1}$ along with foliar application of Se $\left(20 \mu \mathrm{g} \mathrm{L}^{-1}\right)$. The least vine length $(114.4 \mathrm{~cm}$ and $120.9 \mathrm{~cm})$, number of leaves (46.3 and 49.9), leaf length $(8.8 \mathrm{~cm}$ and $9.2 \mathrm{~cm})$ and leaf breadth $(9.5 \mathrm{~cm}$ and $9.9 \mathrm{~cm})$ in first and second season, respectively were recorded with $1 \mathrm{tEM} \mathrm{ha}^{-1}$ and $2 \mathrm{kgCBF} \mathrm{ha}^{-1}$.On the basis of pooled mean data, highest vine length $(81.7 \mathrm{~cm}, 150.4 \mathrm{~cm}, 211.9 \mathrm{~cm})$, number of leaves $(47.0,77.7$ and 110.9)at 30, 60 and 90 DAS, leaf length $(15.8 \mathrm{~cm})$ and leaf breadth $(16.3$ $\mathrm{cm}$ ) was obtained with 25tFYM ha ${ }^{-1}+2 \mathrm{kgCBF}$ $\mathrm{ha}^{-1}+\mathrm{Se}\left(20 \mu \mathrm{g} \mathrm{L}^{-1}\right)$ as foliar application. The lowest vine length $(33.3 \mathrm{~cm}, 70.4 \mathrm{~cm}$ and 117.7 $\mathrm{cm})$, number of leaves $(12.9,30.9,48.1)$ at 30 , 60 and 90 DAS, leaf length $(9.0 \mathrm{~cm})$ and leaf breadth $(9.7 \mathrm{~cm})$ were obtained in $1 \mathrm{tEM} \mathrm{ha}^{-1}+2$ $\mathrm{kgCBF} \mathrm{ha}^{-1}$.The response of farmyard manure was found to be superior in enhancing the vine length of cucumber due to the availability of higher amount of macro nutrients such as, N, P, $\mathrm{K}$ and its ability to extract the nutrients present in the soil efficiently (Sharma et al. 2009). The reason for the increase in number of leaves is attributed to the higher amount of nitrogen released from FYM which is synthesized into amino acids resulting in formation of complex proteins and hence contribute to better growth by elongation and multiplication of cells. Similar results were reported by Mani and Anburani (2018) in radish. The increase in growth parameters such as, leaf length and leaf breadth might be dueto the role of consortium of 
biofertilizers which have a positive relationship with crop growth by maximizing the solubilizing potential assisting in efficient transformation of nutrients from unavailable form to available form. These results are in accordance with the findings of Sureshkumar and Karuppaiah (2008) and Prasad et al. (2009) in bitter gourd.Accumulation of selenium in plant tissues through foliar application delays the effect of senescence and in addition enhances the growth as the growth promoting response is activated due to the enhanced antioxidative capacity in a selenium applied crop. It also results in marked increase in the activity of antioxidant enzymes and metabolites. The results are similar with those of Djanaguiramanet al. (2005) in soybean, Ramos et al. (2010) in lettuce and Becvort-Azcurraet al. (2012) in tomato.

Table 1: Influence of organic manures and selenium on growth parameters of cucumber

\begin{tabular}{|c|c|c|c|c|c|c|c|c|c|c|c|c|}
\hline \multirow{2}{*}{ Treatment } & \multicolumn{3}{|c|}{ Vine length $(\mathrm{cm})$} & \multicolumn{3}{|c|}{ Number of leaves/vine } & \multicolumn{3}{|c|}{ Leaf length $(\mathrm{cm})$} & \multicolumn{3}{|c|}{ Leaf breadth (cm) } \\
\hline & $\begin{array}{c}\text { Season } \\
\mid\end{array}$ & $\begin{array}{c}\text { Season } \\
\text { II }\end{array}$ & $\begin{array}{l}\text { Pooled } \\
\text { Mean }\end{array}$ & $\underset{\mid}{\text { Season }}$ & $\begin{array}{c}\text { Season } \\
\text { II }\end{array}$ & $\begin{array}{c}\text { Pooled } \\
\text { Mean }\end{array}$ & $\begin{array}{c}\text { Season } \\
\text { I }\end{array}$ & Season & $\begin{array}{c}\text { Pooled } \\
\text { Mean }\end{array}$ & $\begin{array}{c}\text { Season } \\
\mid\end{array}$ & $\begin{array}{c}\text { Season } \\
\text { II }\end{array}$ & $\begin{array}{l}\text { Pooled } \\
\text { Mean }\end{array}$ \\
\hline$\overline{\mathrm{T}_{1}}$ & 147.4 & 156.6 & 152.0 & 66.6 & 70.2 & 68.4 & 10.9 & 11.6 & 11.2 & 11.8 & 12.4 & 12.1 \\
\hline $\mathrm{T}_{2}$ & 123.1 & 131.2 & 127.1 & 51.2 & 57.3 & 54.3 & 9.3 & 9.8 & 9.6 & 10.2 & 10.5 & 10.4 \\
\hline $\mathrm{T}_{3}$ & 139.6 & 148.5 & 144.1 & 62.3 & 65.1 & 63.7 & 10.4 & 11.0 & 10.7 & 11.3 & 11.8 & 11.6 \\
\hline $\mathrm{T}_{4}$ & 182.9 & 190.2 & 186.1 & 86.6 & 97.1 & 91.9 & 13.8 & 14.1 & 13.9 & 14.2 & 14.5 & 14.4 \\
\hline $\mathrm{T}_{5}$ & 191.3 & 199.1 & 195.2 & 94.4 & 103.7 & 99.1 & 14.6 & 14.8 & 14.7 & 15.1 & 15.3 & 15.2 \\
\hline $\mathrm{T}_{6}$ & 158.4 & 167.1 & 162.7 & 72.9 & 78.4 & 75.6 & 11.8 & 12.5 & 12.2 & 12.7 & 12.9 & 12.8 \\
\hline $\mathrm{T}_{7}$ & 169.8 & 178.7 & 174.3 & 79.6 & 86.1 & 82.8 & 12.9 & 13.3 & 13.1 & 13.4 & 13.7 & 13.6 \\
\hline $\mathrm{T}_{8}$ & 209.1 & 214.6 & 211.9 & 108.2 & 113.7 & 110.9 & 15.7 & 15.9 & 15.8 & 16.2 & 16.5 & 16.3 \\
\hline $\mathrm{T}_{9}^{\circ}$ & 114.4 & 120.9 & 117.7 & 46.3 & 49.9 & 48.1 & 8.8 & 9.2 & 9.0 & 9.5 & 9.9 & 9.7 \\
\hline $\mathrm{T}_{10}$ & 132.0 & 139.1 & 135.6 & 57.7 & 61.5 & 59.6 & 9.8 & 10.4 & 10.1 & 10.7 & 11.3 & 11.0 \\
\hline $\mathrm{T}_{11}$ & 154.8 & 165.9 & 160.4 & 71.0 & 76.1 & 73.6 & 11.5 & 12.2 & 11.8 & 12.3 & 12.7 & 12.5 \\
\hline $\mathrm{T}_{12}$ & 165.3 & 174.5 & 169.9 & 78.5 & 84.3 & 81.4 & 12.5 & 13.1 & 12.8 & 13.2 & 13.4 & 13.3 \\
\hline $\mathrm{T}_{13}$ & 177.4 & 186.6 & 182.0 & 85.1 & 96.7 & 90.9 & 13.5 & 13.9 & 13.7 & 13.9 & 14.3 & 14.1 \\
\hline $\mathrm{T}_{14}$ & 190.6 & 197.5 & 193.1 & 93.2 & 101.4 & 97.3 & 14.4 & 14.6 & 14.5 & 14.8 & 15.1 & 14.9 \\
\hline $\mathrm{T}_{15}$ & 198.9 & 206.3 & 202.6 & 100.9 & 108.2 & 104.5 & 15.2 & 15.3 & 15.3 & 15.6 & 15.9 & 15.8 \\
\hline S.ED & 3.26 & 3.55 & 3.41 & 1.06 & 1.18 & 1.12 & 0.24 & 0.25 & 0.25 & 0.21 & 0.24 & 0.23 \\
\hline$C D(p=0.05)$ & 6.52 & 7.10 & 6.81 & 2.12 & 2.36 & 2.24 & 0.48 & 0.50 & 0.49 & 0.42 & 0.47 & 0.45 \\
\hline
\end{tabular}

Yield Parameters

The results (Table 2) revealed thathighest number of fruits per vine (13.3 and 16.5), fruit length $(19.6 \mathrm{~cm}$ and $20.8 \mathrm{~cm})$, fruit girth $(17.1 \mathrm{~cm}$ and $18.2 \mathrm{~cm})$, mean single fruit weight $(78.1 \mathrm{~g}$ and $81.2 \mathrm{~g})$, fruit yield vine ${ }^{-1}$ (723.5 $\mathrm{g}$ and $1009.2 \mathrm{~g}$ ) in first and second season, respectively was obtained with $1 \mathrm{tEM}$ ha ${ }^{1}+2 \mathrm{kgCBF} \mathrm{ha}^{-1}+\mathrm{Se}\left(20 \mu \mathrm{g} \mathrm{L}^{-1}\right)$ as foliar application (Table 2). The least number of fruits per vine (5.2 and 7.1), fruit length $(14.0 \mathrm{~cm}$ and $15.2 \mathrm{~cm}$ ), fruit girth $(10.8 \mathrm{~cm}$ and $12.2 \mathrm{~cm})$, mean single fruit weight $(51.1 \mathrm{~g}$ and $56.3 \mathrm{~g})$, fruit yield vine $^{-1}(238.1 \mathrm{~g}$ and $376.7 \mathrm{~g})$ and estimated fruit yield $\left(6.5\right.$ and $\left.8.1 \mathrm{t} \mathrm{ha}^{-1}\right)$ in first and second season, respectively was recorded with $25 \mathrm{t} F Y M$ $\mathrm{ha}^{-1}+2 \mathrm{~kg} \mathrm{CBF} \mathrm{ha-1}$. On the basis of pooled mean data, highest number of fruits per vine (14.9), fruit length $(20.2 \mathrm{~cm})$, fruit girth $(17.6 \mathrm{~cm})$, mean single fruit weight $(79.6 \mathrm{~g})$, fruit yield vine ${ }^{1}(866.4 \mathrm{~g})$ were obtained in the treatment that received $1 \mathrm{t} \mathrm{EM} \mathrm{ha}^{-1}+2 \mathrm{~kg} \mathrm{CBF} \mathrm{ha}^{-1}+\mathrm{Se}(20$ $\mu \mathrm{g} \mathrm{L}^{-1}$ ) as foliar application. The pooled mean data of least number of fruits per vine (6.1), fruit length $(14.6 \mathrm{~cm})$, fruit girth $(11.5 \mathrm{~cm})$, mean single fruit weight $(53.7 \mathrm{~g})$, fruit yield vine ${ }^{-1}$ $(307.4 \mathrm{~g})$ were recorded with $25 \mathrm{tFYM} \mathrm{ha}^{-1}+2$ $\mathrm{kgCBF} \mathrm{ha}^{-1}$. The number of fruits per plant is the most desirable parameter and is greatly influenced by the application of enriched manure which has efficiently increased the allocation of photosynthesis towards the economic part.Another reason could be due to the longevity of nutrient availability throughout the crop growth phase might have also increased the yield. The increase in yield parameters viz., fruit length, fruit girth may be due to the application of enriched manure at optimum quantity in combination with consortium biofertilizer. These results have been suppoted by Bindiyaet al. (2006), Ghasemet al. (2014) in cucumber and Zekaet al. (2014) in spinach. The similar findings were also reported by Eifediyi and Remison (2010), Arun and Jaya (2014) in cucumber. The increase in fruit length and girth significantly resulted in maximizing the weight of cucumber fruit. The increased fruit 
Table 2: Influence of organic manures and selenium on yield parameters of cucumber

\begin{tabular}{|c|c|c|c|c|c|c|c|c|c|c|c|c|}
\hline \multirow[b]{2}{*}{ Treatment } & \multicolumn{3}{|c|}{ Fruits / vine } & \multicolumn{3}{|c|}{ Fruit length (cm) } & \multicolumn{3}{|c|}{ Fruit girth $(\mathrm{cm})$} & \multicolumn{3}{|c|}{ Mean single fruit wt. (g) } \\
\hline & $\begin{array}{c}\text { Season } \\
1\end{array}$ & $\begin{array}{c}\text { Season } \\
\text { II }\end{array}$ & $\begin{array}{l}\text { Pooled } \\
\text { Mean }\end{array}$ & $\begin{array}{c}\text { Season } \\
\mathrm{I}\end{array}$ & $\begin{array}{c}\text { Season } \\
\text { II }\end{array}$ & $\begin{array}{c}\text { Pooled } \\
\text { Mean }\end{array}$ & $\begin{array}{c}\text { Season } \\
1\end{array}$ & $\begin{array}{c}\text { Season } \\
\text { II }\end{array}$ & $\begin{array}{c}\text { Pooled } \\
\text { Mean }\end{array}$ & $\begin{array}{c}\text { Season } \\
\text { I }\end{array}$ & $\begin{array}{c}\text { Season } \\
\text { II }\end{array}$ & $\begin{array}{l}\text { Pooled } \\
\text { Mean }\end{array}$ \\
\hline$\overline{T_{1}}$ & 6.8 & 8.9 & 7.8 & 15.4 & 16.6 & 16.0 & 12.9 & 14.0 & 13.5 & 60.7 & 62.9 & 61.8 \\
\hline $\mathrm{T}_{2}$ & 5.2 & 7.1 & 6.1 & 14.0 & 15.2 & 14.6 & 10.8 & 12.2 & 11.5 & 51.1 & 56.3 & 53.7 \\
\hline $\mathrm{T}_{3}$ & 6.3 & 8.3 & 7.3 & 14.9 & 16.1 & 15.5 & 12.1 & 13.6 & 12.9 & 58.4 & 60.8 & 59.6 \\
\hline $\mathrm{T}_{4}$ & 8.1 & 10.3 & 9.2 & 16.5 & 17.8 & 17.2 & 14.0 & 15.1 & 14.5 & 65.1 & 67.0 & 66.0 \\
\hline $\mathrm{T}_{5}$ & 8.7 & 11.2 & 9.9 & 17.3 & 18.5 & 17.9 & 14.9 & 15.8 & 15.4 & 67.9 & 70.3 & 69.1 \\
\hline $\mathrm{T}_{6}$ & 9.5 & 12.1 & 10.8 & 18.0 & 19.2 & 18.6 & 15.8 & 16.6 & 16.2 & 70.9 & 73.5 & 72.2 \\
\hline $\mathrm{T}_{7}$ & 8.6 & 10.9 & 9.8 & 17.0 & 18.3 & 17.7 & 14.7 & 15.4 & 15.1 & 67.8 & 69.5 & 68.6 \\
\hline $\mathrm{T}_{8}$ & 10.6 & 13.5 & 12.1 & 18.7 & 20.0 & 19.4 & 16.4 & 17.3 & 16.9 & 73.9 & 76.8 & 75.3 \\
\hline $\mathrm{T}_{9}$ & 5.7 & 7.7 & 6.7 & 14.4 & 15.6 & 15.0 & 11.7 & 13.1 & 12.4 & 54.1 & 58.6 & 56.3 \\
\hline $\mathrm{T}_{10}$ & 7.9 & 10.1 & 9.0 & 16.2 & 17.5 & 16.8 & 13.8 & 14.8 & 14.3 & 64.9 & 66.4 & 65.6 \\
\hline $\mathrm{T}_{11}$ & 10.3 & 13.2 & 11.8 & 18.4 & 19.7 & 19.0 & 16.1 & 17.0 & 16.6 & 73.1 & 75.6 & 74.4 \\
\hline $\mathrm{T}_{12}$ & 12.5 & 15.9 & 14.2 & 19.1 & 20.4 & 19.8 & 16.7 & 17.8 & 17.3 & 75.8 & 78.9 & 77.3 \\
\hline $\mathrm{T}_{13}$ & 7.3 & 9.5 & 8.4 & 15.8 & 17.0 & 16.4 & 13.4 & 14.4 & 13.9 & 63.0 & 65.4 & 64.2 \\
\hline $\mathrm{T}_{14}$ & 9.2 & 11.8 & 10.5 & 17.8 & 19.0 & 18.4 & 15.5 & 16.3 & 15.9 & 69.7 & 72.5 & 71.1 \\
\hline $\mathrm{T}_{15}$ & 13.3 & 16.5 & 14.9 & 19.6 & 20.8 & 20.2 & 17.1 & 18.2 & 17.6 & 78.1 & 81.2 & 79.6 \\
\hline S.ED & 0.20 & 0.25 & 0.23 & 0.19 & 0.21 & 0.20 & 0.16 & 0.18 & 0.17 & 0.90 & 1.06 & 0.98 \\
\hline$C D(p=0.05)$ & 0.51 & 0.56 & 0.54 & 0.38 & 0.41 & 0.40 & 0.32 & 0.36 & 0.34 & 1.80 & 2.11 & 1.96 \\
\hline
\end{tabular}

yield of cucumber might be attributed due to the foliar sprayed selenium treated plants which as a result of improved photosynthesis attained by enhancing ROS scavenging, chlorophyll content, osmolytes balance, antioxidant enzyme activities. These results are in agreement with the previous reports of Pezzarossa et al. (2014)in tomato.

Table 3: Influence of organic manures and selenium on fruit yield and selenium content in cucumber

\begin{tabular}{|c|ccc|c|c|c|}
\hline \multirow{2}{*}{ Treatment } & \multicolumn{3}{|c|}{ Fruit yield per vine $(\mathrm{g})$} & \multicolumn{3}{c|}{ Selenium content in fruit $\left(\mu \mathrm{kg}^{-1}\right)$} \\
\cline { 2 - 7 } & Season I & Season II & Pooled Mean & Season I & Season II & Pooled Mean \\
\hline $\mathrm{T}_{1}$ & 359.2 & 503.8 & 431.5 & 0.1 & 0.9 & 0.5 \\
$\mathrm{~T}_{2}$ & 238.1 & 376.7 & 307.4 & 0.2 & 0.6 & 0.5 \\
$\mathrm{~T}_{3}$ & 320.6 & 459.8 & 390.2 & 0.1 & 1.2 & 1.0 \\
$\mathrm{~T}_{4}$ & 454.3 & 619.3 & 536.8 & 2.1 & 5.2 & 3.7 \\
$\mathrm{~T}_{5}$ & 510.2 & 716.9 & 613.6 & 3.2 & 7.6 & 5.4 \\
$\mathrm{~T}_{6}$ & 564.5 & 795.4 & 680.0 & 0.6 & 0.6 & 0.6 \\
$\mathrm{~T}_{7}$ & 497.3 & 678.8 & 588.0 & 4.0 & 6.1 & 5.0 \\
$\mathrm{~T}_{8}$ & 635.7 & 892.8 & 764.2 & 5.5 & 8.1 & 6.8 \\
$\mathrm{~T}_{9}$ & 278.0 & 419.7 & 348.9 & 0.2 & 0.4 & 0.3 \\
$\mathrm{~T}_{10}$ & 431.8 & 587.1 & 509.5 & 1.8 & 0.9 & 1.3 \\
$\mathrm{~T}_{11}$ & 605.9 & 858.7 & 732.3 & 0.5 & 3.1 & 1.5 \\
$\mathrm{~T}_{12}$ & 676.6 & 950.4 & 813.5 & 2.1 & 3.3 & 2.7 \\
$\mathrm{~T}_{13}$ & 397.8 & 550.8 & 474.3 & 0.7 & 0.9 & 0.8 \\
$\mathrm{~T}_{14}$ & 545.9 & 766.9 & 656.4 & 4.1 & 6.3 & 5.2 \\
$\mathrm{~T}_{15}$ & 723.5 & 1009.2 & 866.4 & 8.1 & 10.6 & 9.3 \\
$\mathrm{~S} . \mathrm{ED}$ & 15.07 & 17.10 & 16.09 & 0.08 & 0.12 & 0.10 \\
$\mathrm{CD}(\mathrm{p}=0.05)$ & 30.14 & 34.20 & 32.17 & 0.16 & 0.24 & 0.19 \\
\hline
\end{tabular}

\section{Selenium content in fruits}

The results were recorded and expressed in $\mu \mathrm{g} \mathrm{kg} \mathrm{kg}^{-1}$. The highest selenium content fruit ${ }^{-1}$ $\left(8.1 \mu \mathrm{g} \mathrm{kg}^{-1}\right.$ and $\left.10.6 \mathrm{\mu g} \mathrm{kg}^{-1}\right)$ were recorded with $1 \mathrm{t} \mathrm{EM} \mathrm{ha}{ }^{-1}+2 \mathrm{~kg} \mathrm{CBF} \mathrm{ha}^{-1}+\mathrm{Se}\left(20 \mathrm{\mu g} \mathrm{L}^{-1}\right)$ as foliar application. The lowest selenium content fruit $^{-1}\left(5.5 \mu \mathrm{g} \mathrm{kg}^{-1}\right.$ and $\left.8.1 \mu \mathrm{g} \mathrm{kg}^{-1}\right)$ in first and second season, respectively were recorded in 25 t FYM ha ${ }^{-1}$ and $2 \mathrm{~kg} \mathrm{CBF} \mathrm{ha}{ }^{-1}$ along with foliar application of $\mathrm{Se}\left(20 \mu \mathrm{g} \mathrm{L}^{-1}\right)$. The highest selenium content $\left(9.3 \mu \mathrm{g} \mathrm{kg}^{-1}\right)$ on pooled bases was recorded with $1 \mathrm{t} \mathrm{EM} \mathrm{ha}{ }^{-1}+2 \mathrm{~kg} \mathrm{CBF} \mathrm{ha}^{-1}+$ Se $\left(20 \mu \mathrm{g} \mathrm{L}^{-1}\right)$ as foliar application (Table 3). 
The least selenium content $\left(6.8 \mu \mathrm{g} \mathrm{kg}^{-1}\right)$ was recorded in25 $\mathrm{t} \mathrm{FYM} \mathrm{ha}{ }^{-1}$ and $2 \mathrm{~kg} \mathrm{CBF} \mathrm{ha}^{-1}$ along with foliar application of Se $\left(20 \mathrm{Mg} \mathrm{L}^{-1}\right)$. The plants supplemented with $20 \mathrm{\mu g} \mathrm{L}^{-1}$ of selenium recorded the maximum accumulation in fruits. This might be due to the foliar spray of

\section{REFERENCES}

A.O.A.C.(2019) Official and tentative method of analysis. Association of official Agricultural chemists, $21^{\text {st }}$ Edition, Washington D.C, U.S.A. 3:58.

Arun, S. and Jaya, K.R. (2014) Influence of nutrient management systems on yield attributes of cucumber (Cucumissativus L. varBeit Alpha) cultivated in Polyhouse conditions. Trends in Biosciences7(21): 3450-3452.

Becvort-Azcurra, A., Fuentes-Lara, L.O., Benavides-Mendoza, A., Ramírez, $H$., Robledo-Torres, V. and RodríguezMendoza, M. (2012) Application of selenium in tomato: effects on plant growth, productivity and fruit antioxidant status. Terra Latinoamericana 30 (4): 291301.

Bindiya, Y., Reddy, I.P., Srihari, D., Narayanamma, M. and Reddy, R. S. (2006) Effect of integrated nutrient management on growth and yield of cucumber (Cucumissativus L.).Journal of Research 34(4):8-1.

Cartes, P., Shene, C. and Mora, M.L. (2006) Selenium distribution in ryegrass and its antioxidant role as affected by sulfur fertilization. Plant and soil 285(1-2):187-195.

Djanaguiraman, M., Devi, D.D., Shanker, A.K., Sheeba, J. A. and Bangarusamy, U. (2004) Impact of selenium spray on monocarpic senescence of soybean (Glycine max L.).Journal of Food Agriculture and Environment 2:44-47.

Eifediyi, E. K. and Remison, S. U. (2009) Effect of time of planting on the growth and yield of five varieties of cucumber (Cucumissativus L.). Report and Opinion 1(5):81-90.

Ghasem, S., Morteza, A. S. and Maryam, T.(2014) Effect of organic fertilizers on cucumber

(Cucumissativus) yield. International Journal of Agriculture and Crop Sciences 7(11):808-814.

Mani, A.P. and Anburani, A. (2018) Organic nutrient management technique for enhancing growth and physiological parameters in radish (Raphanussativus L.). Journal of Phytology 40-42. selenium in the form of sodium selenate $\left(\mathrm{Na}_{2} \mathrm{SeO}_{4}\right)$ which recorded to be efficient due to the accumulation of selenium through sulfate transport pathway coupled to a $\mathrm{H}+-$ ATPase as reported by Terry et al. (2000), Cartes et al. (2006) and Zhao et al. (2010).

Pezzarossa, B., Rosellini, I., Borghesi, E., Tonutti, P.and Malorgio, F. (2014) Effects of Se-enrichment on yield, fruit composition and ripening of tomato (Solanumlycopersicum) plants grown in hydroponics. ScientiaHorticulturae 165:106110.

Prasad, P. H., Mandal, A. R., Sarkar, A., Thapa, U. and Maity, T.K. (2009) Effect of biofertilizers and nitrogen on growth and yield attributes of bitter gourd (Momordicacharantia L). Proceedings, International Conference on Horticulture, $\mathrm{pp}$ 738-739.

Ramos, S. J., Faquin, V., Guilherme, L.R.G., Castro, E.M., Ávila, F.W., Carvalho, G.S. and Oliveira, C. (2010) Selenium biofortification and antioxidant activity in lettuce plants fed with selenate and selenite.Plant, Soil and Environment 56(12):584-588.

Sharma, M.K., Saurabh, N. andSantosh, K. (2009) Effect of different growing media and fertigation levels on production of cucumber (Cucumissativus) under protected conditions in the hills.Indian journal of Agricultural sciences 79(11):853-856.

Sureshkumar, R. andKaruppaiah, P. (2008) Effect of integrated nutrient management on growth and yield of bitter gourd (Momordicacharantia L.) type Mithipagal.Plant Archives 8(2):867-868.

Terry, N., Zayed, A. M., De Souza, M. P. andTarun, A. S. (2000) Selenium in higher plants. Annual review of plant biology 51(1):401-432.

Zeka, N., Mero, G., Skenderasi, B. andGjançi, S. (2014) Effects of nitrogen sources and levels on yield and nutritive values of spinach (Spinaciaoleracea L.).Journal of International Academic Research for Multidisciplinary 2:327-337.

Zhao, X. Q., Mitani, N., Yamaji, N., Shen, R. F.and Ma, J. F. (2010) Involvement of silicon influx transporter OsNIP2; 1 in selenite uptake in rice.Plant Physiology 153(4):1871-1877. 